\title{
Field study results of a 3rd generation roof bolter canopy air curtain for respirable coal mine dust control
}

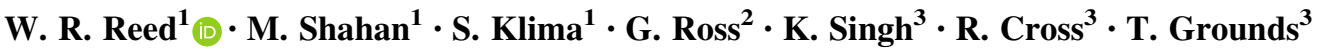

Received: 27 June 2019/Revised: 4 September 2019/Accepted: 26 October 2019/Published online: 14 November 2019

(C) The Author(s) 2019

\begin{abstract}
A 3rd generation roof bolter canopy air curtain (CAC) has been developed and constructed by J.H. Fletcher \& Co., Inc. As with the previous generation of the $\mathrm{CAC}$, this design uses the principle of providing uniform airflow across the canopy area as recommended by the National Institute for Occupational Safety and Health. The new modifications include a plenum that is constructed of a single flat aluminum plate, smaller-diameter airflow openings, and a single row of perimeter nozzles designed to prevent mine air contaminated by respirable dust from entering the CAC protection zone. Field testing was conducted on this new 3rd generation design showing reductions in coal mine respirable dust exposure for roof bolter operators. Dust control efficiencies for the CAC for the left bolter operator (intake side) ranged from approximately $26 \%-60 \%$, while the efficiencies for the CAC for the right bolter operator (return side) ranged from $3 \%$ to $47 \%$.
\end{abstract}

Keywords Roof bolter · Respirable dust · Coal mining · Canopy air curtain

\section{Introduction}

A field investigation was conducted by the National Institute for Occupational Safety and Health (NIOSH) to measure the effectiveness of a 3rd generation roof bolter canopy air curtain (CAC) system in reducing miners' respirable coal mine dust exposure. The canopy air curtain $(\mathrm{CAC})$ is an engineering control intended to protect workers from airborne respirable coal mine dust exposure.

Disclaimer The findings and conclusions in this paper are those of the authors and do not necessarily represent the official position of the National Institute for Occupational Safety and Health, Centers for Disease Control and Prevention. Mention of any company or product does not constitute endorsement by NIOSH.

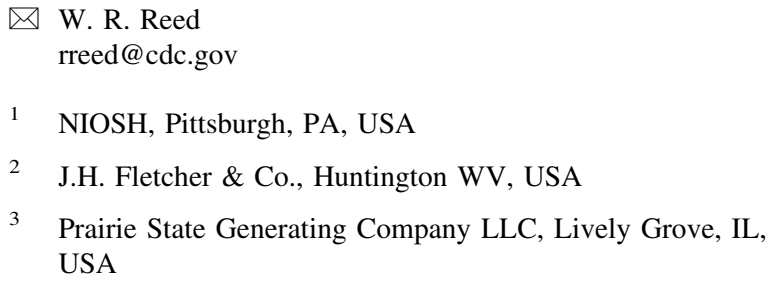


air contaminated with respirable coal mine dust into the plenum protection zone. The plenum face was also constructed of aluminum plating to lighten the weight of the canopy while still providing the strength required. Figure 1 shows the new 3rd generation design. Details of general CAC operation have been described in prior publications (Reed et al. 2017, 2019a; Listak and Beck 2012).

On February 1, 2016, the Mine Safety and Health Administration (MSHA) required the use of the continuous personal dust monitor (CPDM) for sampling respirable coal mine dust (Code of Federal Regulations 2017a). On August 1, 2016, MSHA reduced the coal mine respirable dust standard from 2.0 to $1.5 \mathrm{mg} / \mathrm{m}^{3}$ (Code of Federal Regulations 2015). These changes were made to help reduce coal miners' exposure to respirable coal mine dust. In a review of dust samples taken from April 1, 2016, through June 30, 2016, MSHA stated that approximately $99 \%$ of the respirable coal mine dust samples collected during this time period were in compliance with the dust rule (Mine Safety and Health Administration 2016), citing the use of the CPDM as a compliance tool.

An additional review of the MSHA respirable coal mine dust database from August 1, 2016, through April 2018 was conducted by the NIOSH authors, looking at CPDM data only. The results showed that for the roof bolter operator on the intake side (MSHA occupation code 12), a total of 317 samples were taken with only 1 sample above the $1.5 \mathrm{mg} /$ $\mathrm{m}^{3}$ limit. However, results for the roof bolter operator on the return side (MSHA occupation code 14) showed that 45583 samples were taken with 276 samples above the $1.5 \mathrm{mg} / \mathrm{m}^{3}$ limit (NIOSH review 2018a).

Reviewing the MSHA respirable silica dust database for the same time period shows that the intake roof bolter operator had 19 samples taken with 10 samples having $>5 \%$ quartz. The roof bolter operator on the return side had 2057 samples taken with 1107 samples having $>5 \%$ quartz (NIOSH review 2018b). When quartz is present in respirable dust, the mine is required to maintain the mine atmosphere at or below $0.100 \mathrm{mg} / \mathrm{m}^{3}$ respirable

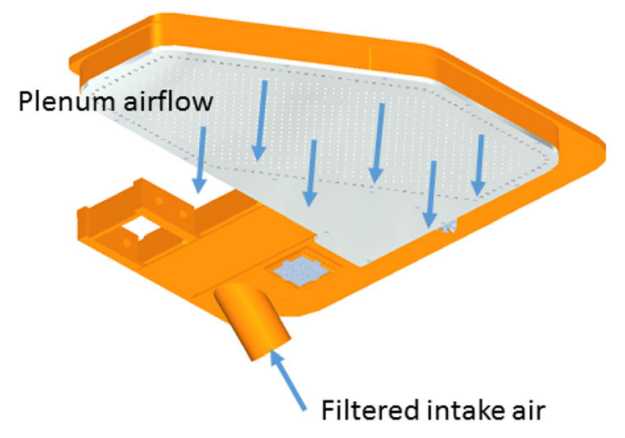

Fig. 1 The 3rd generation roof bolter canopy air curtain. Blue arrows show airflow into the canopy intake and airflow emitting from the canopy plenum quartz dust. The respirable dust standard becomes 10 divided by the percent quartz; however, CFR 70.101 states that application of this formula shall not result in an applicable standard that exceeds the $1.5 \mathrm{mg} / \mathrm{m}^{3}$ respirable dust standard (Code of Federal Regulations 2017b).

While the number of coal mine respirable dust samples cited above that exceed the $1.5 \mathrm{mg} / \mathrm{m}^{3}$ limit are not numerous, they do highlight the challenge of preventing the roof bolter operator's exposure to respirable coal mine dust. Additionally, although the MSHA quartz database does not present overexposures to respirable quartz dust, exposures to respirable quartz or silica dust can still be a significant problem for the mine operator, as seen by the number of samples that exceed 5\% quartz. Therefore, the roof bolter CAC was developed to help mine operators maintain compliance with the $1.5 \mathrm{mg} / \mathrm{m}^{3}$ respirable coal mine dust limit and to protect the roof bolter operator from overexposure.

To determine the effectiveness of the 3rd generation roof bolter CAC in mine operating conditions, a study was conducted at Prairie State Energy's underground coal mine, called the Lively Grove Mine. This room-and-pillar mine contains coal from the Herrin \#6 seam and produces approximately 7 million tons of coal per year to the adjacently located power plant. The mine employs a blowing face ventilation system to the dual-boom bolter during bolting operations.

\section{Sampling method}

Respirable dust sampling was conducted over two consecutive days with methods similar to that used in prior CAC field testing, but corrections were made in this study to amend the sampling methodology in comparison to the 2nd generation CAC field study by NIOSH (Reed et al. 2019a). Suggested corrections from that study, verbatim, were as follows:

(1) When sampling with the wearable vest, the pDR [i.e., the PDR-1000] should be placed near the gravimetric inlets. This will keep both sampling devices in the same vicinity when the roof bolter operator is moving around at his station.

(2) Place a sampling package outside the CAC protection zones near the middle area between the two roof bolter operators, and locate it such that it will be able to sample the surrounding airflow outside the CAC zones.

(3) Investigate using the PDM (The PDM is the continuous personal dust monitor that is MSHA approved for compliance respirable dust sampling under Title 30 Part 74 of the Code of Federal 
Regulations) as a sampling device instead of gravimetric samplers. It would be more desirable to conduct the sampling with a PDM in conjunction with a pDR [personalDataRAM]. This would reduce the number of sampling devices that the operator would wear and thus reduce the number of sampling ports or inlets. Sampling ports would still need to be located together in the same vicinity. Sampling using the PDM and pDR would eliminate the need for the operators to wear sampling vests during bolting operations.

(4) Sample more conditions when the roof bolter machine is downwind of the continuous miner to sample the effectiveness of the CAC under higher dust concentrations. Conducting the test in higher dust concentrations would eliminate the problems encountered with the low dust concentrations.

Corrections 1 and 2 were fulfilled by placing the pDR1000 nearby the location of the gravimetric sampler inlets and placing the outside sampling packages as close to operators as possible but outside the protection zone of the CAC.

Correction 3 was not satisfied. The CPDM was not used in this study and overall dust concentrations encountered during the field study were very low. The CPDM was not used because NIOSH has used the combination of gravimetric samplers and the pDR-1000 successfully in the past. NIOSH is reviewing test protocols to substitute the CPDM as a unit to use in the field for personal sampling purposes in future studies. The fact that the CPDM was not used in this study does not imply inaccuracy of either method of sampling.

Correction 4 was also not satisfied. Obtaining respirable dust concentration results with the roof bolter downwind of the continuous miner was not possible due to timing of the continuous mining cuts and roof bolter entries. Also, NIOSH did not have the opportunity to sample the roof bolter downwind of the continuous miner because that situation never occurred during the study. A future study targeting roof bolting downwind of the continuous miner is being considered.

Both gravimetric and instantaneous samplers were used for testing the CAC for respirable dust control. Respirable dust contains dust particles whose median diameter is $4.0 \mu \mathrm{m}$ (Soderholm 1989; ISO 1993; Lippmann 1995). The gravimetric sampler is a coal mine dust personal sampling unit consisting of an ELF Escort pump operating at $2.0 \mathrm{~L} /$ min, a $10-\mathrm{mm}$ Dorr-Oliver cyclone, and a $37-\mathrm{mm} 5-\mu \mathrm{m}$ PVC filter. The instantaneous sampler used was the pDR1000. Sampling packages, made up of two gravimetric and one instantaneous sampler (pDR-1000), were used to sample respirable dust at different locations in the section. Figure 2 shows the locations of the sampling packages.

Intake samplers (blue and yellow) were located at the entrance and exit of the line curtain into the roof bolting sections. The return sampler (red) was located in the return of the roof bolting section. The roof bolter was outfitted with sampling packages (purple) at the middle (just behind the canopy) and rear of the center of the roof bolter. The sampling packages were located so they did not interfere with the operator activities. Additionally, each operator was outfitted with a sampling package (green) consisting of one pDR-1000 and two gravimetric samplers, attached to a wearable vest. The gravimetric cyclones' inlets were placed at both the right and left lapels. The pDR-1000 was placed on the front of the operators' vest to correct for the error of sampler placement during the 2 nd generation CAC field study (Reed et al. 2019a). This allowed NIOSH to investigate dust exposures to the roof bolter operator. Roof bolter operators performed their duties as they normally would. No special instructions were provided by NIOSH.

Two additional gravimetric cyclone inlets were placed directly underneath the plenum outflow for each side of the roof bolter. The ELF Escort pumps operating at $2.0 \mathrm{~L} / \mathrm{min}$ were mounted to the roof bolter mast. These samplers were used to monitor the respirable dust concentrations underneath the CAC. The sampler cyclones were positioned so that the inlet openings were oriented pointing downward and were operated continuously whether the operator was underneath the canopy or not.

\section{Testing}

Face ventilation readings were recorded for each roof bolter location using a vane anemometer. Time studies were performed by NIOSH researchers on the roof bolter operators during the survey, documenting the operators' position and noting when they were under the canopy. The NIOSH researchers wore appropriate respiratory protection as needed during the study.

The pDR-1000 data were used to determine the effectiveness of the canopy air curtain by comparing the miner's respirable dust exposure to the adjacent middle bolter ambient air measurement, which was located just outside of the zone of protection of the CAC. Dust measurements were collected using the pDR-1000 every $5 \mathrm{~s}$. The CAC was operating the entire time during roof bolting operations. However, as in a previous study (Reed et al. 2019a), the roof bolter never operated downwind of the continuous miner. 


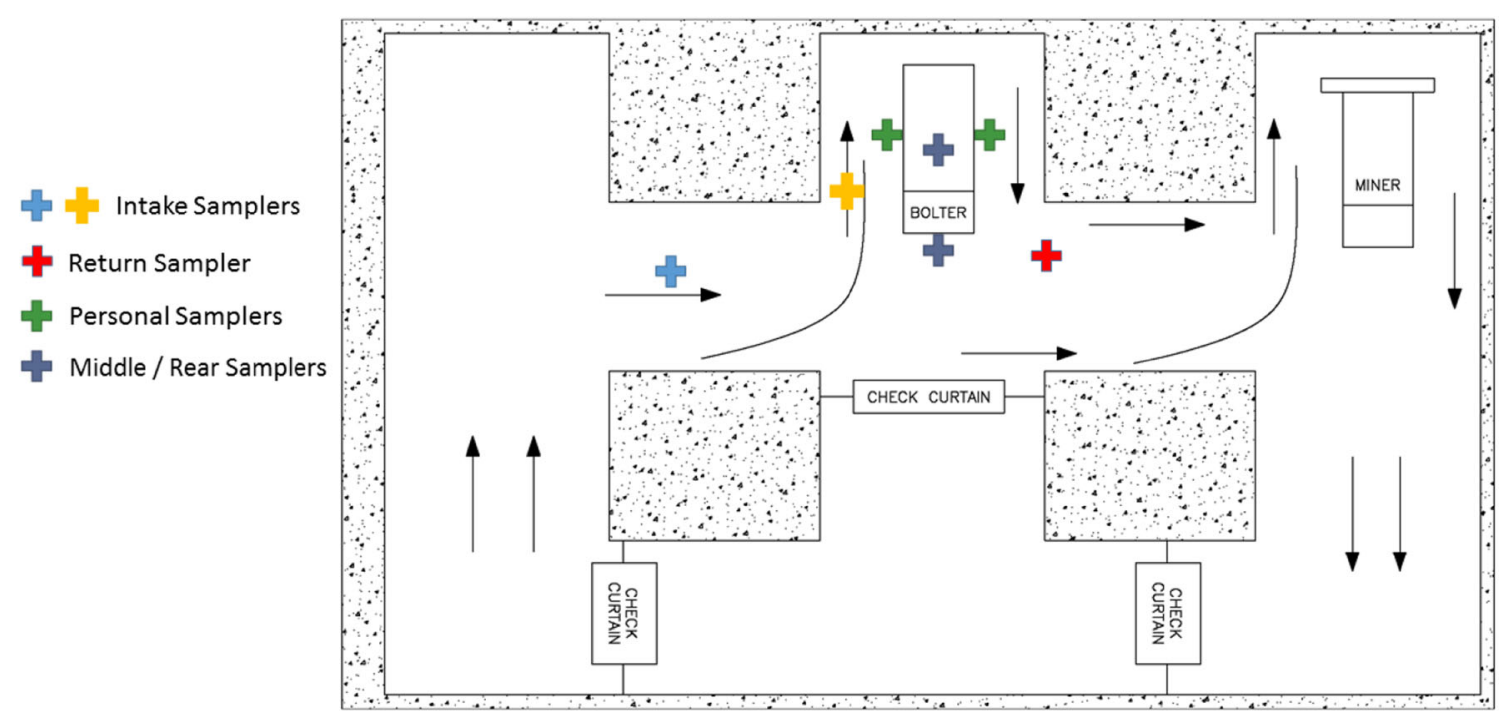

Fig. 2 Locations of sampling packages for testing the dust control efficiency of the roof bolter canopy air curtain

\section{Results and discussion}

Table 1 presents the entry dimensions and the ventilation airflow information for each location where the bolter operated during the study. In Entry 12 Right, a curtain was not hung and the full entry was considered to be the intake.

The gravimetric time-weighted average respirable dust concentrations are reported in Table 2, showing that the respirable dust concentrations measured at the site were very low. The table also shows the concentrations during the entire time for each day at the study site. Table 3 presents the time-weighted average respirable dust concentrations measured from the gravimetric samplers directly underneath the roof bolter canopies and the personal samples measured for both roof bolter operators. The gravimetric concentrations for the roof bolter operators include the time underneath the canopy air curtain as well as the time outside the canopy's zone of protection.

From Table 2, it should be noted that the Intake Exit concentration was higher than the Intake Entrance concentration on both days of testing. On day 1 there was visible dust being generated when hanging new curtain during the roof bolter machine's advance, which explains the concentration difference. The higher respirable dust concentrations corroborate the conjecture (Reed et al. 2019a) that dirty line curtains can contribute to miner exposure to respirable coal mine dust.

Table 3 depicts the dust control efficiency of the canopy air curtain when the operators were under the canopy. These average concentrations were calculated using the instantaneous pDR-1000 data. In order to compare the data among the different pDR-1000s used in the study, the pDR1000 data must be corrected because it is a light scattering instrument (Williams and Timko 1984). Correction is accomplished using a gravimetric sampler along with the pDR-1000. The data from the two types of samplers are used to calculate a calibration ratio with the following equation:

Ratio $=\frac{\text { Grav }}{\text { Instant }}$

where Ratio $=$ the calibration ratio; Grav $=$ the gravimetric TWA concentration; Instant $=$ the instantaneous optical TWA concentration from the pDR-1000.

Table 1 Airflow velocity and quantity at each location

\begin{tabular}{llllr}
\hline Place & Height $(\mathrm{cm})$ & Curtain width $(\mathrm{cm})$ & Airflow velocity $(\mathrm{m} / \mathrm{s})$ & Airflow quantity $\left(\mathrm{m}^{3} / \mathrm{s}\right)$ \\
\hline Entry 11 & 211 & 114 & 1.07 & 2.57 \\
Entry 10 & 229 & 122 & 0.91 & 2.55 \\
Entry 13 & 231 & 117 & 1.03 & 2.77 \\
Entry 8 left & 234 & 96 & 1.15 & 2.59 \\
Entry 9 & 236 & 109 & 1.26 & 3.25 \\
Entry 12 right & 244 & 597 & 0.89 & 12.94 \\
\hline
\end{tabular}


Table 2 Gravimetric time-weighted average respirable dust concentrations for the roof bolter section

\begin{tabular}{llllll}
\hline Date & $\begin{array}{l}\text { Intake entrance } \\
\text { concentration } \\
\left(\mathrm{mg} / \mathrm{m}^{3}\right)\end{array}$ & $\begin{array}{l}\text { Intake exit } \\
\text { concentration } \\
\left(\mathrm{mg} / \mathrm{m}^{3}\right)\end{array}$ & $\begin{array}{l}\text { Bolter middle } \\
\text { concentration } \\
\left(\mathrm{mg} / \mathrm{m}^{3}\right)\end{array}$ & $\begin{array}{l}\text { Bolter rear } \\
\text { concentration } \\
\left(\mathrm{mg} / \mathrm{m}^{3}\right)\end{array}$ & $\begin{array}{l}\text { Return } \\
\text { concentration } \\
\left(\mathrm{mg} / \mathrm{m}^{3}\right)\end{array}$ \\
\hline Oct 26 & 0.015 & 0.276 & 0.233 & 0.048 & 0.057 \\
Oct 27 & 0.210 & 0.228 & 0.416 & 0.183 & 0.182 \\
\hline
\end{tabular}

Table 3 Gravimetric time-weighted average respirable dust concentrations for underneath the roof bolter canopy and bolter operators

\begin{tabular}{|c|c|c|c|c|c|}
\hline Date & $\begin{array}{l}\text { Left side under canopy } \\
\text { concentration }\left(\mathrm{mg} / \mathrm{m}^{3}\right)\end{array}$ & $\begin{array}{l}\text { Right side under canopy } \\
\text { concentration }\left(\mathrm{mg} / \mathrm{m}^{3}\right)\end{array}$ & $\begin{array}{l}\text { Left side operator } \\
\text { concentration }\left(\mathrm{mg} / \mathrm{m}^{3}\right)\end{array}$ & $\begin{array}{l}\text { Right side operator } \\
\text { concentration }\left(\mathrm{mg} / \mathrm{m}^{3}\right)\end{array}$ & $\begin{array}{l}\text { Time } \\
(\min )\end{array}$ \\
\hline October 26 & 0.067 & 0.050 & 0.128 & 0.146 & 140 \\
\hline October 27 & 0.166 & 0.289 & 0.268 & 0.301 & 420 \\
\hline
\end{tabular}

Table 4 Dust control efficiency based on time underneath the canopy air curtain

\begin{tabular}{llllllll}
\hline Date & Location & $\begin{array}{l}\text { Left bolter } \\
\left(\mathrm{mg} / \mathrm{m}^{3}\right)\end{array}$ & $\begin{array}{l}\text { Right bolter } \\
\left(\mathrm{mg} / \mathrm{m}^{3}\right)\end{array}$ & $\begin{array}{l}\text { Left bolter } \\
\text { middle }\left(\mathrm{mg} / \mathrm{m}^{3}\right)\end{array}$ & $\begin{array}{l}\text { Right bolter } \\
\text { middle }\left(\mathrm{mg} / \mathrm{m}^{3}\right)\end{array}$ & $\begin{array}{l}\text { Left dust } \\
\text { control Eff }(\%)\end{array}$ & $\begin{array}{l}\text { Right dust } \\
\text { control Eff }(\%)\end{array}$ \\
\hline October 26 & Entry 11 & 0.197 & $\mathrm{ND}$ & 0.487 & $\mathrm{ND}$ & 59.5 & ND \\
October 26 & Entry 10 & 0.156 & $\mathrm{ND}$ & 0.319 & $\mathrm{ND}$ & 51.0 & ND \\
October 27 & Entry 13 & 0.240 & 0.296 & 0.326 & 0.305 & 26.4 & 2.8 \\
October 27 & Entry 8 Left & 0.299 & 0.299 & 0.430 & 0.416 & 30.4 & 28.1 \\
October 27 & Entry 9 & 0.334 & 0.566 & 0.647 & 0.637 & 48.4 & 11.2 \\
October 27 & Entry 12 Right & 0.239 & 0.286 & 0.447 & 0.539 & 46.6 & 47.0 \\
\hline
\end{tabular}

$N D$ no data

Next, the calibration ratio is multiplied by each instantaneous optical concentration recorded by the pDR-1000 in order to obtain absolute instantaneous concentrations. All subsequent calculations were completed using the corrected pDR-1000 data.

The operators' exposure shown in Table 4 was compared to the closest sampler located outside of the canopy air curtain stream, which was the middle bolter sampler. The distances between the sampling devices (bolter operator and middle bolter) are not large $(<10 \mathrm{ft}$.) and the airborne respirable dust generally has a long residence time before settling (Bhaskar et al. 1986). Therefore, any settling of coal dust that may occur due to gravity is insignificant. These two factors and the method of protection provided to the operator by the CAC (blowing clean filtered air over the operator) would eliminate any concern of bias due to gravitational settling.

The right bolter operator's pDR-1000 malfunctioned on the first day of testing; therefore, instantaneous concentrations could not be determined. The average concentrations in Table 4 differ from the gravimetric time-weighted averages previously calculated in Tables 2 and 3, because the averages in Table 4 only include the time underneath the canopy in the calculations, while the operators' gravimetric averages in Tables 1 and 2 include the time the operators were both underneath and outside the CAC.

To calculate the average dust concentration for the entry, the time segments that the roof bolter operators worked under the canopy for each row of bolts were used. Once a row of bolts was completed the operators moved from underneath the CAC to move the bolting machine forward. The pDR-1000 data were averaged for each time segment in the entry. To calculate an average for the entire entry, each segment was time-weighted averaged, taking the summation of the average concentration of each segment multiplied by the segment time and dividing the summation by the total time of the segments. The dust control efficiency for the CAC was calculated for the left or right bolter operator using:

$\%$ Efficiency $=1-\frac{\text { Left or Right bolter concentration }}{\text { Bolter middle concentration }}$

In reviewing the results from Table 4, the left bolter was generally on the intake air side of the blowing face ventilation while the right bolter was on the exhaust or return side of the blowing face ventilation. Entry 12 right was an exception as it was a cross-cut that was "broken through," 
resulting in intake air flowing over the bolter machine with the return air flowing into Entry 13.

Analysis of variance (ANOVA) was used to determine the statistical significance of the data sets that were used for calculating the dust control efficiencies. The instantaneous concentrations of each bolter operator (left and right) were compared to the corresponding instantaneous concentrations of the bolter middle samplers. Results of the ANOVA with 95\% confidence using Microsoft Excel are shown in Tables 5 and 6. The Microsoft Excel ANOVA analysis uses the F-distribution, calculating an F-statistic to measure the means of different samples to determine if they are significantly different or not. If the calculated F-statistic is greater than $\mathrm{F}$ critical $\left(\mathrm{F}_{\text {crit }}\right)$, which is determined from F-distribution tables, then the null hypothesis that all averages are equal can be rejected. Because $\mathrm{F}>\mathrm{F}_{\text {crit }}$, the ANOVA showed that the left and right bolter operators' data sets are statistically different from the bolter middle sampler data set. This supports the argument that the operators' reduced respirable dust exposures were influenced positively by the CAC. Similar control efficiencies were observed in the lab when testing this canopy design, supporting the results collected in the field (Reed et al. 2017, 2019b).

It can be seen from Table 4 that the roof bolter operators were provided protection from coal mine respirable dust exposure while working underneath the CAC, as the dust control efficiency ranges from $51.0 \%$ to $59.5 \%$ for the left roof bolter on October 26th. The amount of time spent directly underneath the canopy is important as the left bolter worked underneath the canopy for $62 \mathrm{~min}$ out of $140 \mathrm{~min}$ on October 26th. For October 27th, the dust control efficiencies ranged from $26.4 \%$ to $48.4 \%$ for the left roof bolter. The left bolter operator worked $173 \mathrm{~min}$ under the CAC out of the $420 \mathrm{~min}$ the study was conducted.

The dust control efficiencies for the right roof bolter were only available for October 27 th because the pDR1000 sampler failed on October 26th. The dust control efficiencies ranged from $2.8 \%$ to $47.0 \%$. Again, the amount of time the operator spent underneath the CAC is important. The right bolter operator worked $212 \mathrm{~min}$ under the CAC out of 420 min the study was conducted.

There was an additional roof bolter location in Entry 8 Right on Oct 27 that was measured during this study. In this entry, the dust reductions were negative indicating increases in dust concentrations at the operator positions. This location was different from all others because cable bolts were being installed instead of roof bolts. The installation of cable bolts requires extra movements of the roof bolter operator in and out of the CAC protection zone, which could not be documented accurately. Moving in and out of the CAC protection zone can eliminate the ability of the CAC to protect the operator. Therefore, while important to note, this location was omitted from the analysis. It should be noted that while working in this location, roof bolter exposure to respirable dust was low, with the right bolter's average concentration being $0.082 \mathrm{mg} / \mathrm{m}^{3}$ and the left bolter's average being $0.088 \mathrm{mg} / \mathrm{m}^{3}$. The bolter middle average concentration was $0.063 \mathrm{mg} / \mathrm{m}^{3}$.

It should also be noted that the sampler inlets were anywhere from 74 to $84 \mathrm{~cm}$ below the CAC plenum, if the plenum was directly above the operator's hardhat. Many times during this study, the plenum was well above the operator's hardhat, greatly increasing the distance between the plenum and breathing zone. Past research has been conducted on the spatial variability of the location of the sampling inlet within the operator's breathing zone for personal sampling. This spatial variability was found to be negligible for lapel and forehead sampling inlet locations in uniformly dispersed aerosols, i.e., the bias calculated for each location, lapel and forehead, was found to be equivalent (Cohen et al. 1983). Further research conducted on personal sampling location in coal mining applications was conducted and found that the cap lamp sampling location is a better indicator of dust concentration at the nose level than the lapel location. However, the effect was small, and spatial variability of dust levels in the mine and imprecision of personal samplers had a greater influence on dust concentration measurement than location of sampling inlet (Vinson et al. 2007). Therefore, distance between sampling inlet locations within the breathing zone minimally influences dust concentration measurement.

However, past research has shown that the CAC loses effectiveness as distance between the breathing zone and plenum increases (Reed et al. 2017; Goodman and Organiscak 2001). The downward airflow of the CAC provides protection to operator, but it tends to allow potentially contaminated ventilation airflow into the CAC protection zone at distances further away from the plenum

Table 5 Summary of left bolter operator analysis of variance

\begin{tabular}{lllllllll}
\hline Groups & Count & Sum & Average & Variance & $d f$ & F & $P$ value & $\mathrm{F}_{\text {crit }}$ \\
\hline Left bolter & 2853 & 656.2731 & 0.230029 & 0.10713 & 1 & 159.5072 & $\approx 0.00$ & 3.84309 \\
Left middle & 2853 & 1183.2490 & 0.414738 & 0.50311 & N/A & N/A & N/A & N/A \\
\hline
\end{tabular}


Table 6 Summary of right bolter operator analysis of variance

\begin{tabular}{lllllllll}
\hline Groups & Count & Sum & Average & Variance & $d f$ & F & $P$ value & F crit \\
\hline Right bolter & 2568 & 835.5103 & 0.325354 & 0.98850 & 1 & 14.0827 & $1.77 \mathrm{E}-04$ & 3.84327 \\
Right middle & 2568 & 1071.5580 & 0.417273 & 0.55219 & N/A & N/A & N/A & N/A \\
\hline
\end{tabular}

Table 7 Theoretical maximum dust reduction efficiency

\begin{tabular}{llllll}
\hline Date & $\begin{array}{l}\text { Bolter middle } \\
\text { concentration } \\
\left(\mathrm{mg} / \mathrm{m}^{3}\right)\end{array}$ & $\begin{array}{l}\text { Left side under } \\
\text { canopy concentration } \\
\left(\mathrm{mg} / \mathrm{m}^{3}\right)\end{array}$ & $\begin{array}{l}\text { Right side under } \\
\text { canopy concentration } \\
\left(\mathrm{mg} / \mathrm{m}^{3}\right)\end{array}$ & $\begin{array}{l}\text { Left side maximum } \\
\text { reduction eff. }(\%)\end{array}$ & $\begin{array}{l}\text { Right side maximum } \\
\text { reduction eff. }(\%)\end{array}$ \\
\hline October 26 & 0.233 & 0.067 & 0.050 & 71.2 & 78.6 \\
October 27 & 0.416 & 0.166 & 0.289 & 60.1 & 30.4 \\
\end{tabular}

Table 8 Dust control efficiency averages of times the roof bolter operator worked underneath the canopy air curtain in each entry

\begin{tabular}{llllllll}
\hline Date & Location & $\begin{array}{l}\text { Left bolter } \\
\left(\mathrm{mg} / \mathrm{m}^{3}\right)\end{array}$ & $\begin{array}{l}\text { Right bolter } \\
\left(\mathrm{mg} / \mathrm{m}^{3}\right)\end{array}$ & $\begin{array}{l}\text { Left bolter } \\
\text { middle }\left(\mathrm{mg} / \mathrm{m}^{3}\right)\end{array}$ & $\begin{array}{l}\text { Right bolter } \\
\text { middle }\left(\mathrm{mg} / \mathrm{m}^{3}\right)\end{array}$ & $\begin{array}{l}\text { Left dust } \\
\text { control eff }(\%)\end{array}$ & $\begin{array}{l}\text { Right dust } \\
\text { control eff }(\%)\end{array}$ \\
\hline October 26 & Entry 11 & 0.103 & $\mathrm{ND}$ & 0.487 & $\mathrm{ND}$ & 78.8 & ND \\
October 26 & Entry 10 & 0.081 & $\mathrm{ND}$ & 0.319 & $\mathrm{ND}$ & 74.6 & ND \\
October 27 & Entry 13 & 0.148 & 0.183 & 0.326 & 0.305 & 54.6 & 57.0 \\
October 27 & Entry 8 Left & 0.185 & 0.185 & 0.430 & 0.416 & 68.2 & 55.5 \\
October 27 & Entry 9 & 0.206 & 0.350 & 0.647 & 0.637 & 67.1 & 67.2 \\
October 27 & Entry 12 Right & 0.147 & 0.177 & 0.447 & 0.539 & 67.0 \\
\hline
\end{tabular}

$N D$ no data

(Reed et al. 2017). Therefore, distance between plenum and breathing zone is an important factor in CAC protection.

Therefore, a maximum dust reduction efficiency while working underneath the CAC can be calculated using the gravimetric filters that were attached to the underside of the canopy air curtains. This maximum dust reduction efficiency was calculated using the following equation:

$\%$ Efficiency $=1-\frac{\text { Underside concentration }}{\text { Bolter middle concentration }}$

The underside canopy concentration filters were fixed to the underside of the canopy air curtain for the duration of the test and were operated continuously whether the operator was underneath the canopy or not. Table 7 shows the theoretical maximum dust control efficiency based upon the gravimetric time-weighted average concentrations that resulted during the study. This ranged from $60.1 \%$ to $71.2 \%$ for the left bolter operator and $30.5 \%$ to $78.5 \%$ efficiency for the right bolter operator. These dust control efficiencies represent what the roof bolter operators possibly could have encountered if they had remained underneath the canopy during the entire study time span.

Table 8 shows the maximum dust control efficiency of the $\mathrm{CAC}$ for the time that the roof bolter operator worked in the entry installing roof bolts. It can be seen that the dust control efficiency can vary from entry to entry, due to differing ventilation, background dust, workplace surroundings, etc. The left roof bolter operator's maximum dust control efficiency ranged from $55 \%$ to $79 \%$, while the right roof bolter operator's ranged from $40 \%$ to $67 \%$.

\section{Conclusions}

A prior NIOSH field study noted deficiencies that occurred during previous sampling of a 2 nd generation roof bolter canopy air curtain for respirable coal mine dust control (Reed et al. 2019a). In the current study of a 3rd generation roof bolter canopy air curtain, this deficiency was corrected 
by placing the pDR-1000 on the front of the roof bolter operators near the gravimetric sampler inlets. A sampling package was placed between the two roof bolter operators as close to the work area as possible, but outside the protection zone. Monitoring of the intake air into the entry was conducted by placing a sampling package at the entrance and exit of the blowing face ventilation line curtain.

Monitoring of the intake samplers showed that a dirty line curtain has the potential to increase respirable dust concentrations to the workers in the entry in blowing face ventilation systems. However, more studies should be completed before a definitive assertion can be made.

Dust control efficiencies of respirable dust for the roof bolter CAC demonstrated reductions of respirable coal mine dust exposure to the roof bolter operators. However, this reduction is only provided when the operator works underneath the CAC. The left roof bolter operator worked 62 min underneath the CAC during the 140-min study on Oct 26, while working 173 min underneath the CAC during the 420-min study on Oct 27. Dust control efficiencies ranged from $26 \%$ to $60 \%$ during both days of the study. The right bolter operator worked 67 min underneath the CAC during the 140-min study on Oct 26. However, no concentration data were available on Oct 26 due to instantaneous sampler malfunction.

The right bolter operator worked 212 min underneath the CAC during the 420-min study on Oct 27 . The dust control efficiencies for the right bolter operator ranged from approximately $3 \%$ to $47 \%$. The possible reason for the lower efficiencies of the right bolter could be because the left bolter operator was on the intake side of the face ventilation system while the right bolter operator was on the return side. The right bolter operator received respirable dust concentrations that were low $(<0.301$ for the study time frame of $420 \mathrm{~min}$ ) but that were generally higher than the left roof bolter operator. The low dust concentrations encountered at the mine site are beyond the control of the study and are a characteristic of this particular mining operation.

A maximum efficiency was calculated to show the potential of a properly positioned CAC during operator activities while underneath the CAC. The maximum dust control efficiency for the left roof bolter ranged from 55\% to $79 \%$, while the right roof bolter efficiencies ranged from $40 \%$ to $67 \%$. However, the reported dust control efficiencies ranging from $26 \%$ to $60 \%$ (left bolter operator) and $3 \%$ to $47 \%$ (right bolter operator) from Table 4 demonstrate that the CAC is an effective dust control device to control respirable coal mine dust.

Open Access This article is distributed under the terms of the Creative Commons Attribution 4.0 International License (http://crea tivecommons.org/licenses/by/4.0/), which permits unrestricted use, distribution, and reproduction in any medium, provided you give appropriate credit to the original author(s) and the source, provide a link to the Creative Commons license, and indicate if changes were made.

\section{References}

Bhaskar R, Raman RV, Jankowski RA (1986) Experimental studies on dust dispersion in mine airways. In: SME-AIME annual meeting, New Orleans, LA, March 2-6, 1986. Pre-print \#:86140. Society of Mining Engineers of AIME, Littleton, CO

Code of Federal Regulations (2015) CFR 70.100, code of federal regulations, 70.100 Respirable dust standards. CFR Title 30, Chapter I, Subchapter O, Part 70, Subpart B, 70.100. U.S. Government Printing Office. National Archives and Records Administration, Washington, DC

Code of Federal Regulations (2017a) CFR 70.201, code of federal regulations, 70.201 Sampling; general and technical requirements. CFR Title 30, Chapter I, Subchapter O, Part 70, Subpart C, 70.201. U.S. Government Printing Office. National Archives and Records Administration, Washington, DC

Code of Federal Regulations (2017b) CFR 70.101, code of federal regulations, 70.101 Respirable dust standard when quartz is present. CFR Title 30, Chapter I, Subchapter O, Part 70, Subpart B, 70.101. U.S. Government Printing Office. National Archives and Records Administration, Washington, DC

Cohen BS, Harley HH, Martinelli CA, Lippmann M (1983) Sampling artifacts in the breathing zone. In: Marple VA, Liu BYH (eds) Aerosols in the mining and industrial work environment, vol 1. Ann Arbor Science, Ann Arbor, MI, pp 347-360

Goodman GVR, Organiscak JA (2001) Laboratory evaluation of a Canopy Air Curtain for controlling occupational exposures of roof bolters. In: Proceedings of the seventh international mine ventilation congress. EMAG, Cracow, Poland, pp 299-305

International Standards Organization (ISO) (1993) Air qualityparticle size fraction definitions for health-related sampling. In: Draft international standards ISO technical report, ISO/TR 7708-1983 (E), ISO, Geneva

Lippmann M (1995) Size-selective health hazard sampling. In: Cohen BS, Hering SV (eds) Chapter 5, Air sampling instruments for evaluation of atmospheric contaminants, 8th edn. American conference of governmental industrial hygienists, ACGIH, Cincinnati, OH, pp 81-119

Listak JM, Beck TW (2012) Development of a canopy air curtain to reduce roof bolters' dust exposure. Min Eng 64(7):72-79

Mine Safety and Health Administration (2016) MSHA finds nearly all respirable coal dust samplings comply with new standards to lower levels of respirable coal dust. Website: MSHA.gov. https://www.msha.gov/msha-finds-nearly-all-respirable-coaldust-samplings-comply-new-standards-lower-levels-respirable. Accessed 16 May 2018

NIOSH review of Mine Safety and Health Administration (2018a) Coal dust samples data set. U.S. Department of Labor website. https://arlweb.msha.gov/OpenGovernmentData/OGIMSHA. asp\#msha-datasets. Accessed 16 May 2018

NIOSH review of Mine Safety and Health Administration (2018b) Quartz Samples. U.S. Department of Labor website. https:// arlweb.msha.gov/OpenGovernmentData/OGIMSHA.asp\#mshadatasets. Accessed 16 May 2018

Reed WR, Joy GJ, Kendall B, Bailey A, Zheng Y (2017) Development of a roof bolter canopy air curtain for respirable dust control. Min Eng 69(1):33-39

Reed WR, Klima S, Shahan M, Ross G, Singh K, Cross R, Grounds T (2019a) A field study of a roof bolter canopy air curtain (2nd 
generation) for respirable coal mine dust control. Int J Min Sci Technol. https://doi.org/10.1016/j.ijmst.2019.02.005

Reed WR, Joy GJ, Shahan M, Klima S, Ross G (2019b) Laboratory results of a 3rd generation roof bolter canopy air curtain for respirable coal mine dust control. Int J Coal Sci Technol 6(1):15-26

Soderholm SC (1989) Proposed international conventions for particle size selective sampling. Ann Occup Hyg 33(3):301-320
Vinson R, Volkwein J, McWilliams L (2007) Determining the spatial variability of personal sampler inlet locations. J Occup Environ Hyg 4(9):708-714. https://doi.org/10.1080/15459620701540618

Williams K, Timko R (1984) Performance evaluation of a real-time aerosol monitor. Information Circular 8968, U.S. Department of the Interior, U.S. Bureau of Mines, Pittsburgh, PA 